\title{
Production optimization for a conceptual model through combined use of polymer flooding and intelligent well technology under uncertainties
}

\author{
Marcio Augusto Sampaio Pinto ${ }^{1}$; David Sigifredo Montoya Herrera²; Juan Camilo González Angarita ${ }^{2 *}$ \\ ${ }^{1}$ Escola Politécnica da Universidade de São Paulo. Praça Narciso de Andrade - Vila Mathias. Santos, Brazil. \\ ${ }^{2}$ Universidad Industrial de Santander (UIS). Carrera 27 Calle 9. Bucaramanga, Colombia. \\ *E-mail: ingjcamilo22@gmail.com
}

\begin{abstract}
To mitigate high reservoir heterogeneities and fluids mobility differences, oil industry has developed methodologies and technologies like recovery methods at reservoir level, and intelligent completion system at well level. Polymer flooding is a method used to enhance the sweep efficiency in order to lead as much oil as possible to the producer wells, meanwhile the intelligent well technology allows to manage the flow of fluids into the wellbore, thus reducing water production and its costs involved. This work aims to study the behavior change of production due to the implementation in parallel of polymer flooding and intelligent well technology through conceptual reservoir simulations, risk management and geological and economic uncertainty analysis. Furthermore, it was stablished the resulting profit as main comparison criterion, under a simplified Brazilian fiscal regime. It was verified the largest project profit increase due to the combined use of both technologies.
\end{abstract}

Keywords: Intelligent Wells, Polymer Flooding, Oil and Gas Production, Reservoir Simulation, Uncertainties, Economic Analysis, Brazil.

\section{Optimización de la producción para un campo conceptual a través del uso combinado de inyección de polímero y tecnología de pozo inteligente}

\section{Resumen}

Con el fin de mitigar las altas heterogeneidades presentes en los yacimientos y la diferencia de movilidad de los fluidos, la industria petrolera ha desarrollado metodologías y tecnologías a nivel de yacimiento conocidas como métodos de recobro, y a nivel de pozo como el sistema de completamiento inteligente. La inyección de polímero es un método que mejora la eficiencia de barrido con el fin de contactar la mayor cantidad posible de hidrocarburos a los pozos productores, mientras que la tecnología de pozo inteligente permite administrar el flujo de fluidos en el pozo y de esta manera, reducir la producción de agua y los costos que implica. Este trabajo tiene como objetivo estudiar el cambio en el comportamiento de la producción debido a la implementación en paralelo de la inyección de polímero y la tecnología de pozo inteligente por medio de simulaciones de un yacimiento conceptual, gestión de riesgo y análisis de incertidumbre económica y geológica. Así mismo, se estableció la rentabilidad generada como principal criterio de comparación, bajo un régimen fiscal brasilero simplificado. Se verificó el mayor incremento en la rentabilidad del proyecto a causa del uso combinado de ambas tecnologías.

Palabras clave: Pozos Inteligentes, Inyección de Polímero, Producción de Petróleo y Gas, Simulación de Yacimientos, Incertidumbre, Análisis Económico, Brasil.

\section{Introduction}

Oilfields development has been presenting different issues challenging even the modern engineering. High water production rates are usually involved due to high mobility ratio and reservoir heterogeneity, creating a negative impact on the field development (Velandia, 2013). A lot of options have been employed to mitigate it, for example, EOR methods help to attain a better displacement efficiency, just like a polymeric solution

Cita: Sampaio, M. A., Montoya, D. S. \& González, J.C. (2018). Production optimization for a conceptual model through combined use of polymer flooding and intelligent well technology under uncertainties. Revista Fuentes: El reventón energético, $16(1), 37-45$ 
injection improving the conventional water flooding and achieving a more homogenous displacement (Galvis, Suárez \& Navarro, 2013).

Polymer flooding consists on applying a polymeric material to the injection water, which can strongly improve the sweep efficiencies (Molano, Navarro \& Díaz, 2014). Although a reduction in the average molecular weight could take place due to mechanical, thermal, chemical, or biological degradation of polymer, this is a good method to optimize a waterflooding process, because the polymer let it possible to reduce the mobility ratio, increasing oil recovery and reducing water cut (Yuming et al. , 2013). However, it is one of the different methods which could be applied to a reservoir level, and general landscape offers a lot of more points to keep working.

The wells performance is another parameter which has been analyzed its feasibility to be modified with novel engineering systems, to attain a better production behavior. Intelligent well technology (IWT) is a relatively new method, which uses a set of devices to make it possible to get flexible control from surface over production fluids flow, through each pay zone of the well individually. The system is based in swelling elastomer packers to isolate each zone, wireline from surface to bottom hole for data management, sensors to capture information and inflow control valves (ICVs) to choking flow pursuant of be required (Ordoñez, Velez \& Florez, 2015).

The production performance thus can be enhanced from ways which involve a process through the reservoir, and others with just a completion modification (Páez, González \& Duarte, 2016). Both mentioned technologies have a great potential and could result interesting to implement them simultaneously. In this sense, the focus for this study is to combine a polymer injection process with IWT to the producer wells, the feasibility to apply them was studied using reservoir simulation, together and individually for an offshore conceptual field. Also, this work involves a risk and uncertainty analysis of polymer flooding with IWT, acting together.

\section{Statement of theory}

\section{Polymer flooding}

It is a chemical enhanced oil recovery (CEOR) method, in which a large macromolecule is used to increase the displacing fluid viscosity and lead to better vertical and areal sweep efficiencies (Terry, 2001). Polymer flooding (PF) is designed to improve sweep efficiency by reducing the mobility ratio. Polymers are large-molecular-weight molecules added to an injected water to increase its viscosity, improving the effectiveness of a conventional waterflooding (Alvarado \& Manrique, 2010). However, it is important to consider the main issues involved for this method, like polymer degradation and its adsorption at reservoir.

\section{Intelligent wells}

They are wells with an intelligent completion system which is capable of monitoring production and reservoir data, and controlling downhole production (and injection) processes without any well interventions to help maximize the asset value (Ajayi \& Konopczynski, 2003). The monitoring systems count with permanent downhole pressure and temperature sensors supplying reservoir information to a surface data gathering system. The controlling capability is accomplished by using a hydraulic, electric, or electrohydraulic control valves (ICVs). Each ICV can either be a binary on/ off system or have variable chocking system (García \& Saldanha, 2016).

The application of intelligent well technology (IWT) provides a capability to remotely control, monitor and manage multiple zones in each well. It has provided significant value, through its ability to manage multiple zones independently, reduce total number of wells, reduce number of expensive well interventions, and accelerate the production of zones to maintain a plateau for extended period of time (Ajayi \& Konopczynski, 2003). Initially used in subsea wells, where intervention is very expensive and present high-risk, intelligent completions have proven their value in managing production from multilateral wells, horizontal wells with multiple zones, wells in heterogeneous and mature reservoirs. Figure 1 shows an example of the intelligent completion system applied to a producer well. It is worth mentioning that IWT can be applied to producer and injector wells, it allows to individualize the flows for each zone. Nevertheless, this study contemplates only the implementation in the producer well of the conceptual field, reason the study did not consider mechanical degradation of the polymer by the flow through ICVs.

\section{Risk management}

Volatility and risk are latent factors which nowadays affect different industries, and the Oil \& Gas is not exempt. A lot of uncertainties could be involved around an oilfield project, usually are geological by low reservoir data, economic by country or company 
policies and oil price, and technical by equipment failures (Quinteiro, 2008). Risk management is necessary due to the high degree of uncertainty that can be managed in oil \& gas projects (Pari, Kabir, Motahhari \& Behrouz, 2009). There are typically used three methods to analyze the project risk involved: decision trees, Monte Carlo simulation and real options theory; the first one was implemented for this study (Díaz et al. ,2012).
The comparison between all cases was based about the net present value (NPV) obtained from the economic analysis due to production fluids, following a simplified Brazilian fiscal regime. Also, there was evaluated the expected monetary value (EMV) of each strategy for further analysis, risk management and to generate representative conclusions about implementation of both technologies. Equation 1 shows how it was calculated the EVM values using two probability levels involved in this study, due to geological and economic uncertainties.

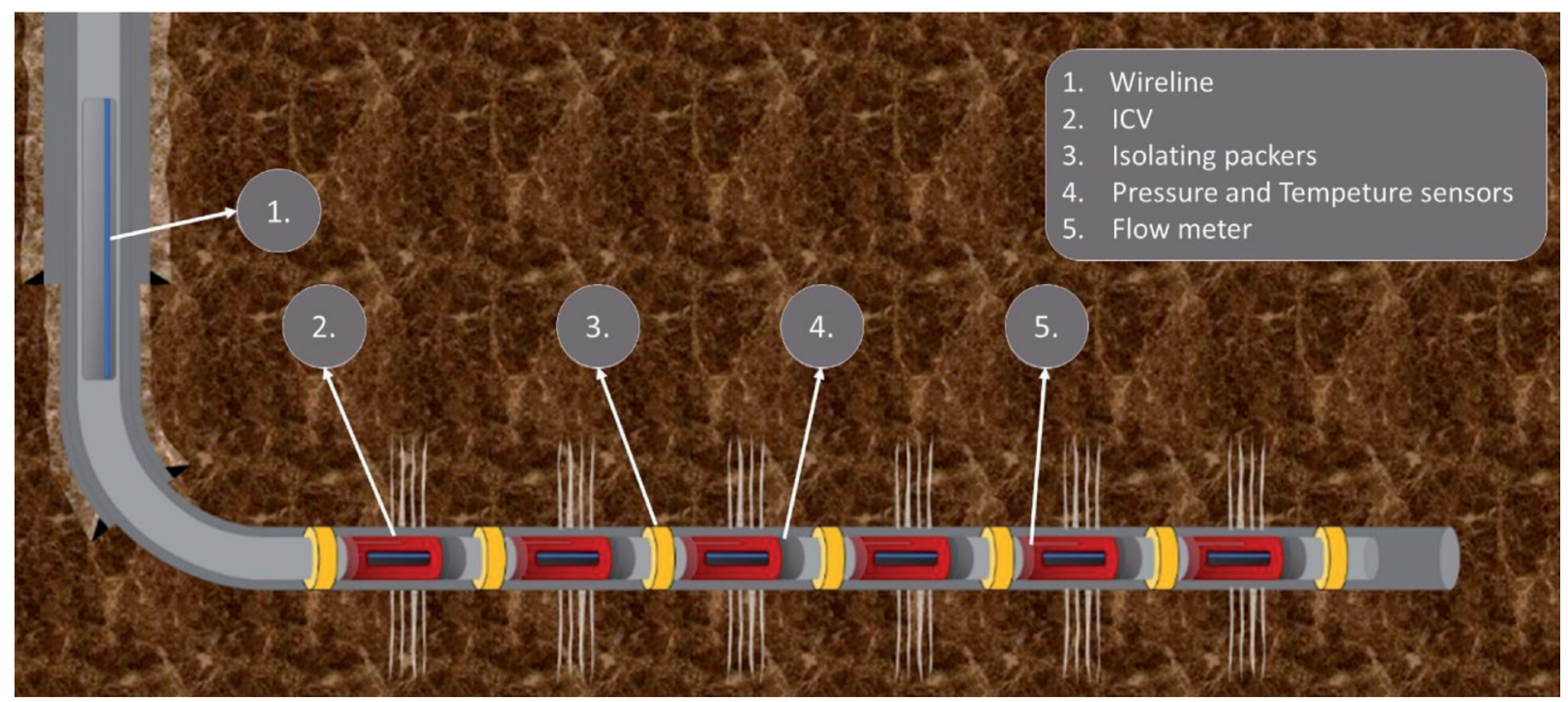

Figure 1. Intelligent completion system.

$$
E M V=\Sigma_{i=1}^{n} \Sigma_{j=1}^{m} p_{i, j} * N P V_{i, j}
$$

Where: $p_{i, j}$ is the case probability, $N P V_{i, j}$ is the case NPV, $n$ is the number of geological models and $m$ the number of economic scenarios.

\section{Methodology}

\section{Stage 1. conventional water management}

At first, a water injection process was simulated, and the wells constraints were optimized using the CMG DECE method in the CMOST module (CMG) with the NPV as objective function, to achieve the highest performance for the base case.

\section{Stage 2. intelligent well implementation}

At this stage, each simulation file was modified to generate new files with a representation of intelligent completion for the producer well. There was implemented one ICV for each layer, modifying the code to use the water cut as a control variable, to close the flow at the pay zone when it achieves a limit value. Also, were optimized the water cut limit value and the number of valves for each case using the NPV and EMV's values as objective functions. Figure 2 shows the code that represents the ICVs effect.

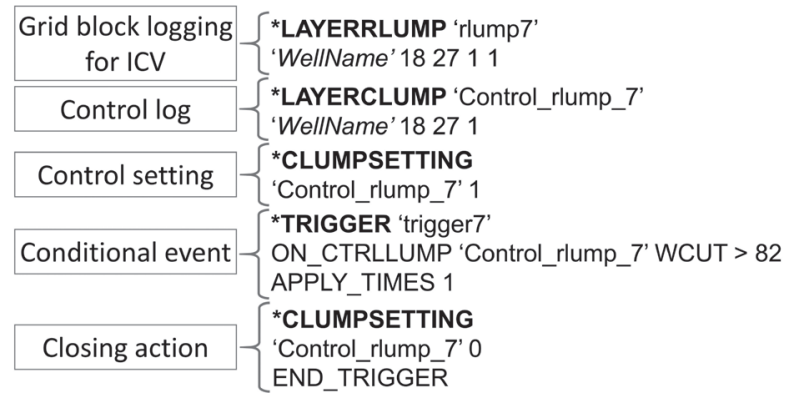

Figure 2. Code lines to represent ICVs effect.

\section{Stage 3. polymer flooding establishment}

It was added a soluble polymeric material on the waterflooding model to simulate and evaluate the polymer injection process. The concentration of 
polymer and the injected pore volumes were optimized using the CMG DECE method in the CMOST module (CMG) with the NPV as objective function, to achieve the highest performance for the polymer flooding case.

\section{Stage 4. both integrated technologies}

It was used the same method at stage 2 to implement the IWT with polymer flooding for this case. Furthermore, the water cut limit value and the number of valves were optimized for each case, using the NPV and EMV as objective functions.

\section{Stage 5. risk and production strategies analysis}

Finally, all results data was used to develop a detailed analysis about risk management and production behavior, pursuant of each applied strategy. Risk curve was plotted, and the simulations results were studied to asset the feasibility for implementing the both technologies (PF and IWT), together and individually.

\section{Case studies}

This work was developed from implementation of the STARS simulator to represent the reservoir and his behavior under adopted conditions, and the CMOST module to optimize different parameters along the study. At first, was built a cubic reservoir model (Figure 3 ) of 10 layers with 16,810 grid blocks, each one with measures of $65.62 \mathrm{ft} \times 65.62 \mathrm{ft} \times 29.5 \mathrm{ft}$; and the presented properties in the Table 1 .

Table 1. Model properties.

\begin{tabular}{ccccc}
\hline $\mathbf{P b}(\mathbf{p s i})$ & $\mathbf{P i}(\mathbf{p s i})$ & Tres $\left({ }^{\circ} \mathbf{F}\right)$ & API $\left({ }^{\circ}\right)$ & Depth (ft) \\
\hline 1,600 & 3,500 & 172.4 & 14.7 & $9,834-10,138$ \\
\hline
\end{tabular}

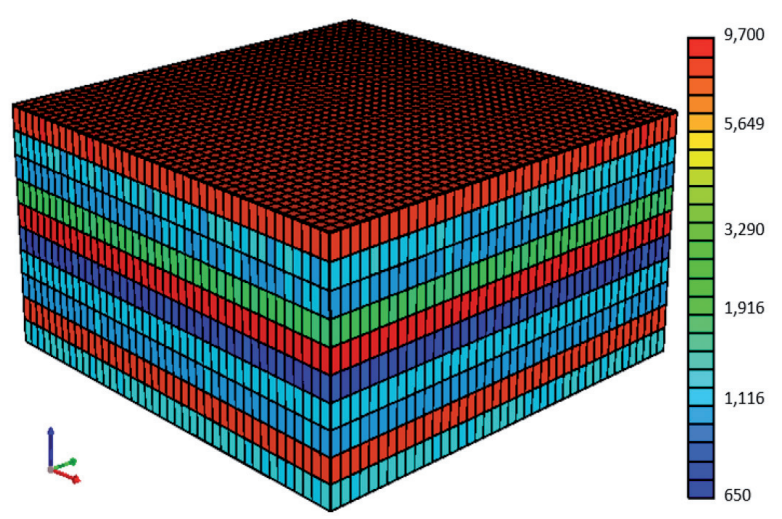

Figure 3. Reservoir model permeability.
Likewise, it was used the PVT data of a field in the Campos Basin. Figure 4 shows the oil formation volume factor (Bo) and the viscosity vs pressure. On the other hand, Figure 5 shows the relative permeability.

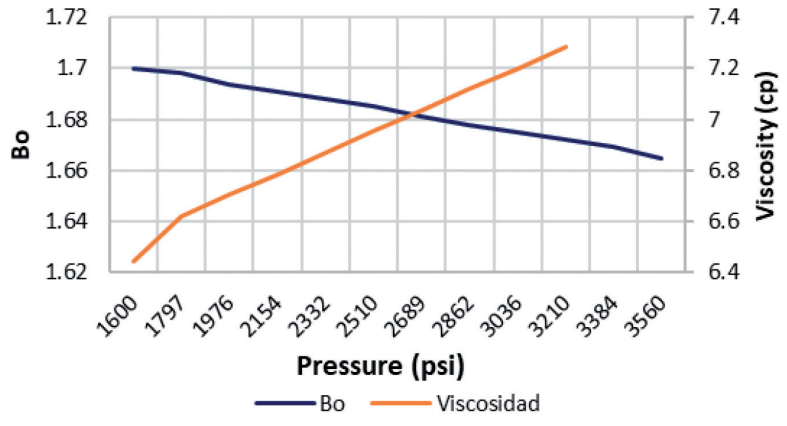

Figure 4. Bo and Viscosity vs Pressure.

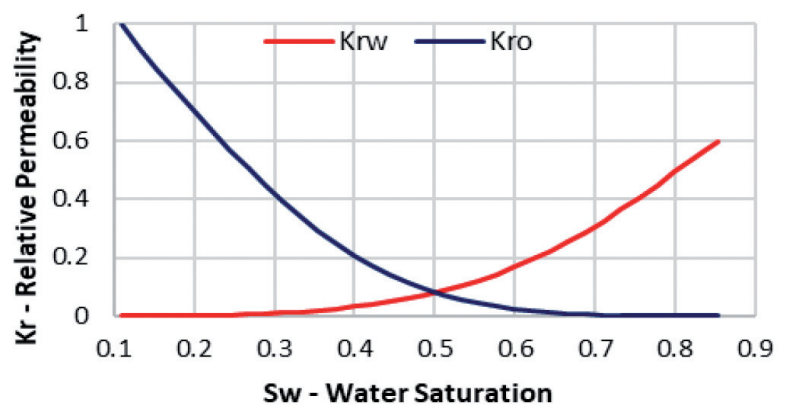

Figure 5. Relative Permeability.

Also, this study involved an uncertainty analysis, thus were created nine possibilities using three geological models (Table 2) under three economic scenarios (Table 3 ), and it was stablished a probability of occurrence for each one (Table 4) as follows.

Table 2. Geological models and their Dykstra-Parsons coefficients.

\begin{tabular}{cc}
\hline Geological Model & Dykstra-Parsons coefficient \\
\hline Heterogeneous 1 (H1) & 0.4721 \\
\hline Heterogeneous 2 $(\mathrm{H} 2)$ & 0.554 \\
\hline Heterogeneous 3 $(\mathrm{H3})$ & 0.6309 \\
\hline
\end{tabular}

Table 3. Economic scenarios data.

\begin{tabular}{cccccc}
$\begin{array}{c}\text { Economic } \\
\text { Scenario }\end{array}$ & $\begin{array}{c}\text { Barrel } \\
\text { Price } \\
\text { (USD/bl) }\end{array}$ & $\begin{array}{c}\text { Oil Prod. } \\
\text { Cost } \\
\text { (USD/bl) }\end{array}$ & $\begin{array}{c}\text { Water } \\
\text { Prod. Cost } \\
\text { (USD/bl) }\end{array}$ & $\begin{array}{c}\text { Water } \\
\text { Injection } \\
\text { Cost } \\
\text { (USD/bl) }\end{array}$ & $\begin{array}{c}\text { Polymer } \\
\text { Cost } \\
\text { (USD/Kg) }\end{array}$ \\
\hline$E S 1$ & 30 & 15 & 1.5 & 1 & 6 \\
$E S 2$ & 45 & 15 & 1.5 & 1 & 6 \\
$E S 3$ & 60 & 15 & 1.5 & 1 & 6 \\
\hline
\end{tabular}


Table 4. Probabilities of occurrence.

\begin{tabular}{|c|c|c|c|c|}
\hline Geological Model & Partial Probability $\left(\mathbf{P}_{\mathbf{i}}\right)$ & Economic Scenario & Partial Probability $\left(\mathbf{P}_{j}\right)$ & Total Probability $\left(\mathbf{P}_{\mathrm{T}}\right)$ \\
\hline \multirow{3}{*}{$\mathrm{H} 1$} & \multirow{3}{*}{0.25} & ES1 & 0.25 & 0.0625 \\
\hline & & ES2 & 0.5 & 0.125 \\
\hline & & ES3 & 0.25 & 0.0625 \\
\hline \multirow{3}{*}{$\mathrm{H} 2$} & \multirow{3}{*}{0.5} & ES1 & 0.25 & 0.125 \\
\hline & & ES2 & 0.5 & 0.25 \\
\hline & & ES3 & 0.25 & 0.125 \\
\hline \multirow{3}{*}{ H3 } & \multirow{3}{*}{0.25} & ES1 & 0.25 & 0.0625 \\
\hline & & ES2 & 0.5 & 0.125 \\
\hline & & ES3 & 0.25 & 0.0625 \\
\hline
\end{tabular}

The polymer parameters were based on literature data (Lamas, 2017) (Cheng et al., 2015) (Lamas, 2012) (Botechia, Correia \& Schiozer 2016) (Zampieri, 2012). It was selected an HPAM polymer, because this polymer type is usually recommended for these kinds of projects (Standnes \& Skjevrak, 2014). Laboratory experiments using rheometer were realized to retrieve dependence of polymer viscosity on concentration (Table 5), shear rate (Table 6) and salinity (Table 7). Also, there were obtained a degradation half-life of 540 days and an adsorption value of $50 \mu \mathrm{g} / \mathrm{g}_{\text {rock }}$. Through sensibility analysis of the polymer injection process, it was determined to inject a slug of 0.3007 pore volumes with 2,000 ppm. Adsorption and permeability reduction demand core flooding experiment.

Table 5. Viscosity vs polymer concentration.

\begin{tabular}{cc}
\hline Polymer Content $(\mathbf{p p m})$ & Viscosity $(\mathbf{c P})$ \\
\hline 0 & 0.5 \\
500 & 1.32 \\
1,000 & 3.78 \\
1,500 & 10.00 \\
\hline
\end{tabular}

Table 6. Viscosity vs shear rate.

\begin{tabular}{|cc|}
\hline Shear rate $\left(\right.$ day $\left.^{-1}\right)$ & Viscosity $(\mathbf{c P})$ \\
\hline 864 & 10 \\
1,861 & 10 \\
4,010 & 9.9998 \\
8,640 & 9.9992 \\
18,614 & 9.9963 \\
40,103 & 9.9831 \\
86,400 & 9.924 \\
186,143 & 9.6912 \\
401,033 & 9.0494 \\
864,000 & 8.0302 \\
$1,861,431$ & 6.9581 \\
$4,010,333$ & 5.9991 \\
$8,639,999$ & 5.1773 \\
$18,614,314$ & 4.4797 \\
$40,103,324$ & 3.8889 \\
$86,399,995$ & 3.3888 \\
\hline
\end{tabular}

Table 7. Viscosity vs salinity.

\begin{tabular}{cc} 
Added $\mathrm{NaCl}(\mathbf{w t} \%)$ & Viscosity $(\mathbf{c P})$ \\
\hline 1.00 & 10.33 \\
2.00 & 7.28 \\
3.00 & 6.36 \\
4.00 & 5.87 \\
5.00 & 5.54 \\
\hline
\end{tabular}

There was implemented a five-spot (four injection wells in each corner and one production well in the center of the reservoir) pattern with waterflooding as initial production strategy, and the wells constraints were optimized improving the performance of the base case (Table 8).

Table 8. Wells optimized constraints.

\begin{tabular}{ccc}
\hline \multirow{2}{*}{ Constraints } & \multicolumn{2}{c}{ Well Type } \\
\cline { 2 - 3 } & Injectors & Producer \\
\hline Max. BHP (psi) & 3,400 & - \\
Min. BHP (psi) & - & 1,000 \\
Max. STL (bbl/day) & - & 9,450 \\
\hline
\end{tabular}

Once built the base case, the simulation file was modified again to add the IWT and polymer flooding to evaluate their combined effect. Therefore, this study presents the following cases:

- Case 1: waterflooding with conventional producer.

- Case 2: waterflooding with intelligent producer.

- Case 3: polymer flooding with conventional producer.

- Case 4: polymer flooding with intelligent producer.

\section{Results and discussions}

The information showed below presents the following considerations:

1. There are exposed data of cumulative oil produced $(\mathrm{Np})$, cumulative water produced (Wp), cumulative water injected (Winj), polymer injected amount and NPV; pursuant of each case. 
2. The results of the cases 2,3 and 4 , are presented as a comparison with the base case (case 1), and the exact values are presented using tables.

3. The production time is different for each case, the project is finished upon the NPV turns negative.
Stage 1 . The cases presented at this stage were evaluated using the first production strategy (water flooding with conventional producer well) and Table 9 shows the detailed results.

Table 9. Case 1 results.

\begin{tabular}{|c|c|c|c|c|c|c|c|c|c|}
\hline & \multicolumn{3}{|c|}{ H1 } & \multicolumn{3}{|c|}{ H2 } & \multicolumn{3}{|c|}{ H3 } \\
\hline & ES1 & ES2 & ES3 & ES1 & ES2 & ES3 & ES1 & ES2 & ES3 \\
\hline$N p(M b b l)$ & 14.6 & 16.1 & 17.3 & 12.4 & 14.7 & 15.9 & 12.3 & 14.5 & 16.2 \\
\hline$W p(M b b l)$ & 29 & 44.7 & 64.2 & 32.4 & 57.7 & 77.1 & 36 & 61.3 & 87.2 \\
\hline Winj (Mbbl) & 42.5 & 59.7 & 80.4 & 43.9 & 71.5 & 92.1 & 47.4 & 75 & 102.6 \\
\hline$N P V$ (MUSD) & -4.07 & 87.17 & 177.39 & -34.3 & 47.33 & 125.95 & -41.07 & 40.32 & 118.59 \\
\hline
\end{tabular}

Stage 2. The implementation of intelligent completion allowed mostly an increase of $\mathrm{Np}$, offering a good water managing as following:

- Np average variation: $+13 \%$

- Wp average variation: $0 \%$
- Winj average variation: $+3 \%$

Also, all cases achieved an improvement on NPV, with a minimum increase of 4.64 MUSD and a maximum of 41.69 MUSD. Table 10 shows detailed data obtained at this stage.

Table 10. Case 2 results.

\begin{tabular}{|c|c|c|c|c|c|c|c|c|c|}
\hline & \multicolumn{3}{|c|}{ H1 } & \multicolumn{3}{|c|}{ H2 } & \multicolumn{3}{|c|}{ H3 } \\
\hline & ES1 & ES2 & ES3 & ES1 & ES2 & ES3 & ES1 & ES2 & ES3 \\
\hline$N p(M b b l)$ & 15.8 & 17.5 & 18.7 & 15.1 & 16.5 & 18.4 & 16.3 & 16.3 & 16.3 \\
\hline$W p(M b b l)$ & 32.4 & 50.7 & 71.3 & 33.9 & 49.7 & 82.3 & 47.8 & 47.8 & 47.8 \\
\hline Winj (Mbbl) & 47.3 & 67.2 & 89.1 & 48.1 & 65.3 & 99.9 & 63.4 & 63.4 & 63.4 \\
\hline$N P V(M U S D)$ & 0.57 & 94.34 & 186.43 & -8.81 & 80 & 167.64 & -11.36 & 75.17 & 157.95 \\
\hline
\end{tabular}

Stage 3. The polymer flooding process showed higher $\mathrm{Np}$ and NVP values, but now with a notable decrease of managed water ( $\mathrm{Wp}$ and $\mathrm{Wi}$ ) even with a conventional completion for the producer well. The variations in comparison with the case 1, were obtained as follows:

- Np average variation: $+15 \%$
- Wp average variation: $-23 \%$

- Winj average variation: $-40 \%$

- NPV increase: min. of 13.96 MUSD and max. of 60.93 MUSD

Table 11 presents the results of the case

Table 11. Case 3 results.

\begin{tabular}{cccccccccccc} 
& \multicolumn{3}{c}{} & H1 & & & H2 & & \multicolumn{3}{c}{ H3 } \\
\cline { 2 - 10 } & ES1 & ES2 & ES3 & ES1 & ES2 & ES3 & ES1 & ES2 & ES3 \\
\hline Np $(M B l)$ & 17.1 & 18.3 & 18.9 & 15.8 & 16.4 & 17.2 & 15.4 & 16.5 & 17.3 \\
Wp $(M B l)$ & 28.3 & 40.9 & 50.6 & 29 & 35.3 & 48.3 & 29.4 & 42.1 & 55.1 \\
Winj $(M B l)$ & 29.5 & 42.3 & 52.5 & 28.7 & 34.8 & 48 & 28.7 & 41.3 & 54.8 \\
Polymer. (Mkg) & 60.5 & 60.5 & 60.5 & 65 & 65 & 65 & 64.8 & 64.8 & 64.8 \\
NPV (MUSD) & 9.89 & 109.33 & 206.58 & -3.79 & 92.38 & 186.88 & -8.15 & 85.45 & 177.5 \\
\hline
\end{tabular}

Stage 4. The combination of both technologies results in the highest increases on NPV and Np values, but lower reductions on water volumes managed than in the previous stage. Variations presented as follows: 
- Np average variation: $+22 \%$

- Wp average variation: $-16 \%$

- Winj average variation: $-34 \%$

- NPV increase: min. of 12.34 MUSD and max. of

\subsection{MUSD}

Table 12 shows the results of the last case.

Table 12. Case 4 results.

\begin{tabular}{|c|c|c|c|c|c|c|c|c|c|}
\hline & \multicolumn{3}{|c|}{ H1 } & \multicolumn{3}{|c|}{ H2 } & \multicolumn{3}{|c|}{ H3 } \\
\hline & ES1 & ES2 & ES3 & ES1 & ES2 & ES3 & ES1 & ES2 & ES3 \\
\hline$N p(M B l)$ & 19 & 19 & 19 & 17.2 & 17.2 & 17.2 & 16.6 & 17.7 & 20 \\
\hline$W p(M B l)$ & 46 & 46 & 46 & 29.8 & 29.8 & 29.8 & 28 & 40.6 & 83.1 \\
\hline Winj (MBl) & 47.9 & 47.9 & 47.9 & 30.5 & 30.5 & 30.5 & 28.6 & 41.1 & 85.6 \\
\hline Polymer. (Mkg) & 60.3 & 60.3 & 60.3 & 61.5 & 61.5 & 61.5 & 64.7 & 64.7 & 64.7 \\
\hline$N P V(M U S D)$ & 8.27 & 110.26 & 207.67 & 8.05 & 106.26 & 202.4 & 2.62 & 102.36 & 198.7 \\
\hline
\end{tabular}

Stage 5. The implementation of IWT and PF generate large alterations about the project profitability from increasing the cumulative oil produced, reducing cumulative water produced and changing the productive life time of the field. Figure 6 shows these changes for the geological model $\mathrm{H} 2$ and economic scenario
ES2, and presents cases 2 and 4 reaching higher NPV/ EMV than cases 1 and 3 respectively. Also, there is presented the acceleration of oil production rate due to IWT effects and the highest efficiency from both technologies application (case 4) to mitigate the issues by high mobility ratio and reservoir heterogeneity.
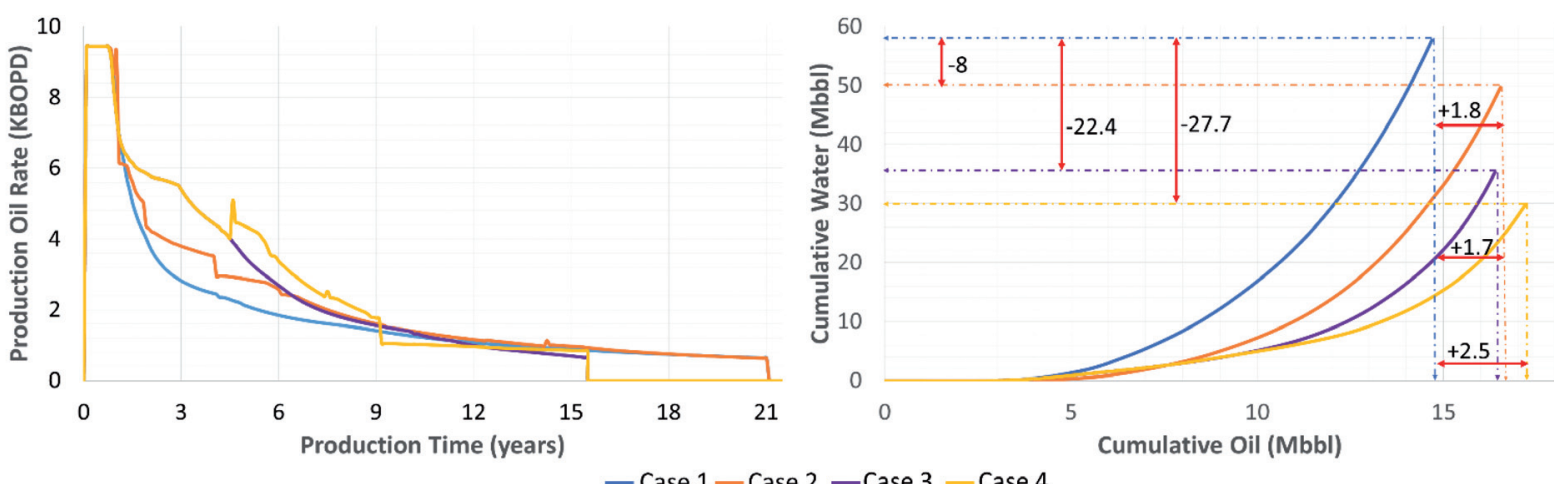

- Case 1 - Case 2 - Case 3 - Case 4

Figure 6. Production behavior (H2-ES2).

The case 4 shows itself as a project development without probability to obtain a negative NPV. However, cases 1 and 2 presents a probability around of $20 \%$ to obtain it, and approximately $15 \%$ for the case 3. The cases 2, 3 and 4 present a lower risk than base case because of higher NPV averages and lower variation coefficients. Table 13 shows the analysis of economic values and Figure 7 the risk curve for the cases performances. Also, there is a probability around of $5 \%$ to achieve the highest NPV.
Table 13. General economic analysis.

\begin{tabular}{ccccc}
\hline $\begin{array}{c}\text { Production } \\
\text { Cases }\end{array}$ & $\begin{array}{c}\text { Average NPV } \\
\text { (MUSD) }\end{array}$ & $\begin{array}{c}\text { Standard } \\
\text { Deviation }\end{array}$ & $\begin{array}{c}\text { Variation } \\
\text { Coefficient }\end{array}$ & $\begin{array}{c}\text { EMV } \\
\text { (MUSD) }\end{array}$ \\
\hline 1 & 57.48 & 75.83 & $132 \%$ & 54.90 \\
\hline 2 & 82.44 & 77.3 & $94 \%$ & 81.89 \\
\hline 3 & 95.11 & 83.4 & $88 \%$ & 94.44 \\
\hline 4 & 105.18 & 85.2 & $81 \%$ & 105.53 \\
\hline
\end{tabular}




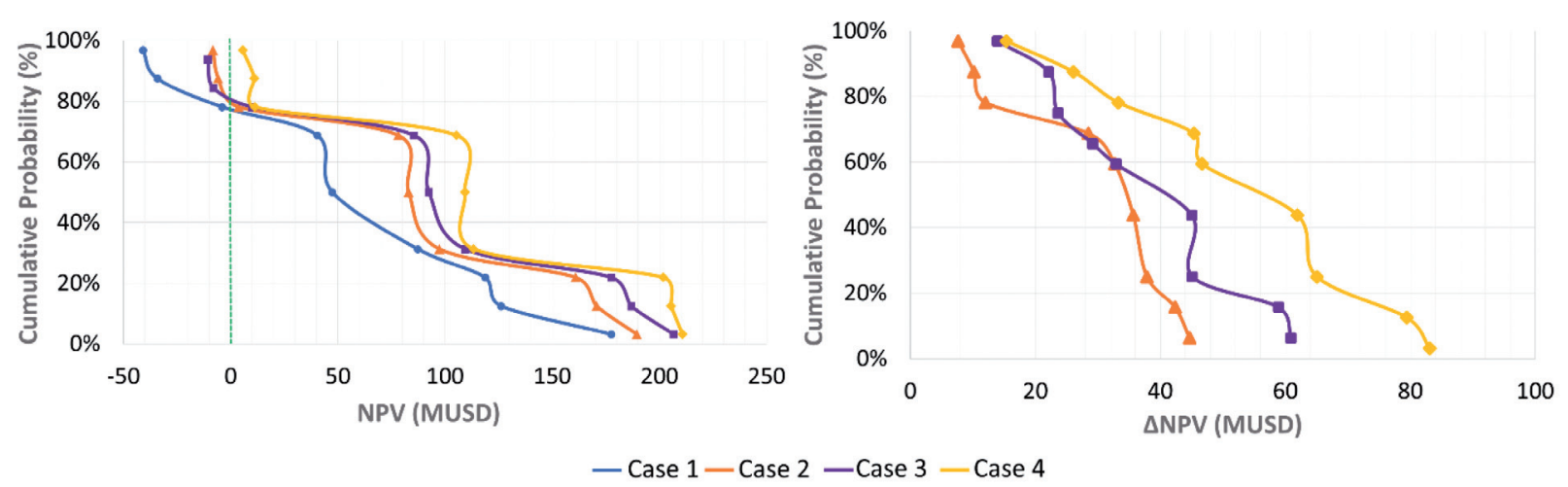

Figure 7. Risk curve for the cases.

\section{Conclusions}

The potential of two technologies can be exploited at the same time to maximize results; nevertheless, the combined use must be analyzed under different real conditions. Therefore, there were calculated DykstraParsons coefficients which corroborated that presented models represent cases with low, medium, and high heterogeneity, to study the showed technologies under geological uncertainty.

The IWT implementation improved the project profitability by itself, increasing the cumulative oil production and reducing the cumulative water production due to its fluids control capability. This technology led an increase of the cumulative water production in some cases. However, it rises the cumulative oil production even more, with an increment of the productive life time of the field.

Also, polymer flooding achieved the highest water volumes reduction maintaining an increase for the cumulative oil production. Furthermore, implementing the intelligent completion to the producer well, allowed to obtain the highest cumulative oil production values with larger increase that the water managed reduction.

Furthermore, the combined implementation of both technologies results in the best production strategy, increasing the NPV for each conditions environment compared to the base case, and thus achieving a higher EMV (nearly 100\% more). Therefore, it means that the IWT applied to the producer wells, can enhance the production efficiency even more despite of implementing previously a polymer flooding process.

Finally, for further studies it is recommendable to use IWT also for the injection wells, considering mechanical degradation of the polymer due to valves. Therefore, an analysis for injectors and its comparison with this initial approach, will allow to determine the main advantages and disadvantages for different levels of integration of both technologies.

\section{Acknowledgements}

The authors thank LASG research group (Escola Politécnica da Universidade de São Paulo) for the commitment to this project. Without their help and assistance, this paper would not have been possible.

\section{Nomenclature}

BHP: Bottom Hole Pressure

Bo: $\quad$ Oil Formation Volume Factor

EMV: Expected Monetary Value

ES: $\quad$ Economic Scenario

ICV: Inflow Control Valve

IWT: Intelligent Well Technology

Np: $\quad$ Cumulative Oil Produced

NPV: $\quad$ Net Present Value

$\mathrm{Pb}$ : $\quad$ Bubble Pressure

PF: $\quad$ Polymer Flooding

Pi: $\quad$ Initial Pressure

STL: $\quad$ Surface Total Liquids

Tres: Reservoir Temperature

WF: Waterflooding

Winj: $\quad$ Cumulative Water Injected

Wp: Cumulative Water Produced

\section{References}

1. Ajayi, A., \& Konopczynski, M. (2003). Simulation of Intelligent Well Completion Predicts Oil Recovery Increase in a Commingled Production Scenario: A Case Study. SPE paper No. 85677. SPE Nigeria Annual International Conference and Exhibition. 
2. Alvarado, V., \& Manrique, E. (2010). Enhanced oil recovery: field planning and development strategies. Gulf Professional Publishing.

3. Botechia, V. E., Correia, M. G., \& Schiozer, D. J. (2016). A Model-Based Production Strategy Selection Considering Polymer Flooding in Heavy Oil Field Development. SPE paper No. 180838. SPE Trinidad and Tobago Section Energy Resources Conference.

4. Chen, J. D., Cui, C., Li, Y. Q., Zhou, L., Ou, Q. D., Li, C., ... \& Tang, J. X. (2015). Single-junction polymer solar cells exceeding $10 \%$ power conversion efficiency. Advanced Materials, 27(6), 1035-1041.

5. Cruz, H. D. O., Duque, J. P. V., \& Marulanda, J. F. F. (2015). Propuesta metodológica para el control y monitoreo de un proceso de inyección de agua. Revista Fuentes, 13(2).

6. Díaz Guardia, V., Castillo Torres, M., Vecino Arenas, C., Hernán Castro, R., Maya Toro, G., \& Bravo Mendoza, O. (2012). Análisis de riesgo y simulación de monte carlo en la valoración de proyectos- aplicación en la industria de los hidrocarburos. Revista Fuentes, 9(2), 33-41.

7. Galvis, F. W. L., Suarez, C. E. N., \& Navarro, S. F. M. (2013). Simulación de un proceso de inyección de agua en un modelo físico escalado $3 \mathrm{~d}$. Revista Fuentes, 11(2).

8. Lamas, L. F. (2012). Comparação entre Estratégias de Produção para Projetos de Injeção de Água e de Polímeros. MSc Dissertation. Campinas: University of Campinas. School of Mechanical Engineering and Institute of Geosciences.

9. Lamas, L. F. (2017). Influence of polymer properties on selection of production strategy for heavy oil fields. PhD Thesis. Campinas: University of Campinas. School of Mechanical Engineering and Institute of Geosciences.

10. Molano, A. M. J., Navarro, S. F. M., \& Díaz, R. J. (2014). Metodología para el diseño de baches en un proceso de inyección de polímeros para recobro mejorado, considerando fenómenos de interacción roca/fluidos. Fuentes: El reventón energético, 12(2), 6.

11. Páez, E. G. M., González, F. E. C., \& Duarte, C. A. M. (2016). Aplicación de series de tiempo en la realización de pronósticos de producción. Fuentes: El reventón energético, 14(1), 79-88

12. Pari, M. N., Kabir, A. H., Motahhari, S., \& Behrouz, T. (2009). Smart well-Benefits, Types of Sensors, Challenges, Economic Consideration, and Application in Fractured Reservoir. SPE paper No. 126093. SPE Saudi Arabia Section Technical Symposium.

13. Quinteiro, J. P. (2008). Uso de poços inteligentes em desenvolvimento de campos de petroleo sob incertezas. MSc Dissertation. Campinas: University of Campinas. School of Mechanical Engineering and Institute of Geosciences.

14. Standnes, D. C., \& Skjevrak, I. (2014). Literature review of implemented polymer field projects. Journal of Petroleum Science and Engineering, 122, 761-775.

15. Terry, R. E. (2001). Enhanced oil recovery. Encyclopedia of physical science and technology, 18, 503-518.

16. Velandia, J. L. P. (2013). Simulación numérica del flujo bifásico agua-petróleo en un medio poroso. Fuentes: El reventón energético, 11(2), 10.

17. Yuming, W., Yanming, P., Zhenbo, S., Peihui, H., Rong, L., Ruibo, C., \& Xianhua, H. (2013). The Polymer Flooding Technique Applied at High Water Cut Stage in Daqing Oilfield. SPE paper No. 164595. SPE North Africa Technical Conference and Exhibition.

18. Zampieri, M. F. (2012). Injeção contínua e alternada de água e de polímeros para a recuperação de petróleo. MSc Dissertation. Campinas: University of Campinas. School of Mechanical Engineering and Institute of Geosciences.

Recepción: 6 de diciembre de 2017

Aceptación: 26 de Abril de 2018 